Article

\title{
New Metabolites and Bioactive Actinomycins from Marine-Derived Streptomyces sp. ZZ338
}

\author{
Xiufang Zhang ${ }^{1}$, Xuewei Ye ${ }^{1}$, Weiyun Chai ${ }^{1}$, Xiao-Yuan Lian ${ }^{2, *}$ and Zhizhen Zhang ${ }^{1, *}$ \\ 1 Ocean College, Zhejiang University, Zhoushan 316021, China; xiufangzhang623@163.com (X.Z.); \\ moshangmowei@163.com (X.Y.); chaiweiyun@163.com (W.C.) \\ 2 College of Pharmaceutical Sciences, Zhejiang University, Hangzhou 310058, China \\ * Correspondence: xylian@zju.edu.cn (X.-Y.L.); zzhang88@zju.edu.cn (Z.Z.); \\ Tel.: +86-135-7547-6388 (X.-Y.L.); +86-136-7585-9706 (Z.Z)
}

Academic Editor: Vassilios Roussis

Received: 21 August 2016; Accepted: 21 September 2016; Published: 11 October 2016

\begin{abstract}
An extract prepared from the culture of a marine-derived actinomycete Streptomyces sp. ZZ338 was found to have significant antimicrobial and antiproliferative activities. A chemical investigation of this active extract resulted in the isolation of three known bioactive actinomycins (1-3) and two new metabolites (4 and 5). The structures of the isolated compounds were identified as actinomycins D (1), V (2), $X_{0 \beta}$ (3), 2-acetylamino-3-hydroxyl-4-methyl-benzoic acid methyl ester (4), and N-1S-(4-methylaminophenylmethyl)-2-oxo-propyl acetamide (5) based on their nuclear magnetic resonance (NMR) and high resolution electrospray ionization mass spectroscopy (HRESIMS) data as well as their optical rotation. This class of new compound $\mathbf{5}$ had never before been found from a natural resource. Three known actinomycins showed activities in inhibiting the proliferation of glioma cells and the growth of methicillin-resistant Staphylococcus aureus, Escherichia coli, and Candida albicans and are responsible for the activity of the crude extract. Actinomycin D (1) was also found to downregulate several glioma metabolic enzymes of glycolysis, glutaminolysis, and lipogenesis, suggesting that targeting multiple tumor metabolic regulators might be a new anti-glioma mechanism of actinomycin D. This is the first report of such a possible mechanism for the class of actinomycins.
\end{abstract}

Keywords: marine Streptomyces sp. ZZ338; new metabolites; actinomycins; antimicrobial activity; antiproliferative activity; glioma cells; glioma metabolic enzymes

\section{Introduction}

Gliomas are the most aggressive and frequently diagnosed human brain tumors. Despite advances in therapies including chemotherapy, radiotherapy, and surgical resection, the prognosis is still very poor [1]. While chemotherapy has played an important role in the treatment and prevention of cancer, very few drugs have been approved for treating gliomas including temozolomide (TMZ), carmustine, lomustine, and bevacizumab [2]. Furthermore, only TMZ has been independently used for the treatment of gliomas and the efficacy of TMZ remains unsatisfactory [2]. Therefore, there is an urgent need to discover lead compounds for the development of novel anti-glioma drugs.

Many anti-cancer bioactive compounds, originally isolated from marine invertebrates are actually produced by marine microorganisms [3,4]. For example, several anti-cancer metabolites from marine sponges that have progressed to preclinical or clinical trial phases, such as discodermolide, halichondrin B, bryostatin1, and phorboxazole A, may actually be products derived from their microbiotic consortia [5-7]. Therefore, bioactive natural products produced by marine microorganisms are promising sources for the discovery and development of novel anti-glioma drugs or drug leads [7-9]. 
During the course of our ongoing project to discover novel antiglioma agents from marine sources [10-15], a marine-derived actinomycete strain, ZZ338, was isolated from sea squirts grown on coastal rocks. A crude extract prepared from the culture of this isolated strain ZZ338 in Gause's liquid medium showed antimicrobial and antiproliferative activities. A chemical investigation of this bioactive extract resulted in the isolation of three known actinomycins (1-3) and new compound 4. In order to obtain more bioactive metabolites, a second medium of BMPM was also used to culture this isolated strain ZZ338, which produced actinomycin 2 and new compound 5. In this study, we report the isolation and culture of strain ZZ338, the structural elucidation of the new metabolites, and the bioactive evaluation of the isolated compounds against the proliferation of glioma cells and the growth of methicillin-resistant Staphylococcus aureus, Escherichia coli, and Candida albicans.

\section{Results and Discussion}

The isolated strain, ZZ338, was assigned as Streptomyces sp. ZZ338 based on its 16S rDNA gene sequence, which completely ( $99 \%$ identity for a $1396 \mathrm{bp}$ stretch of sequence) matched those of several Streptomyces strains (Supplementary Materials, Figure S1 and Table S1) in the GenBank database. Two different liquid media of Gause and Bristol Myers Production Medium (BMPM) were used to culture this actinomycete, which produced three known actinomycins (1-3) and two new metabolites (4 and 5) (Figure 1).

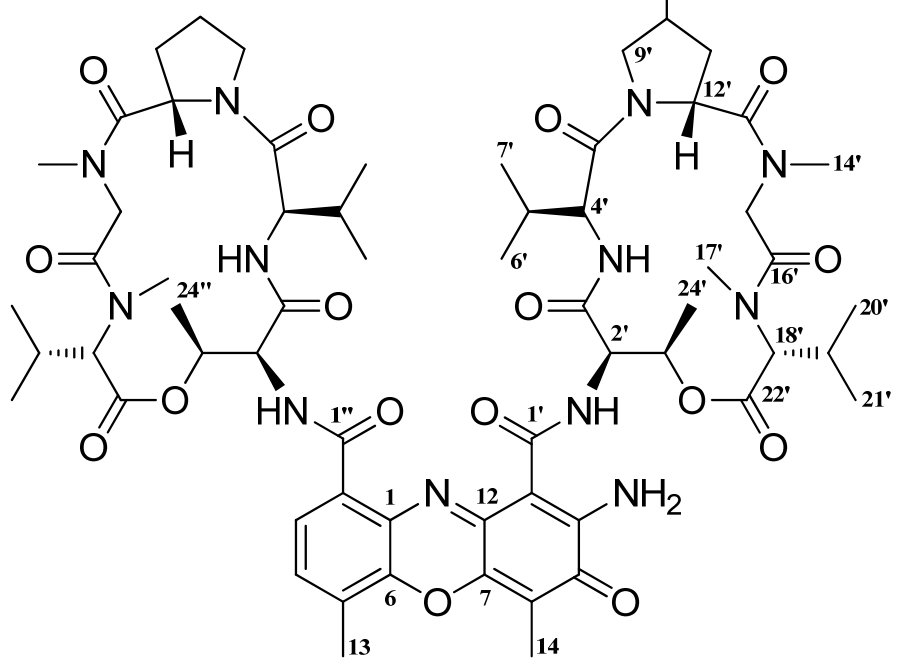<smiles>C=CNc1ccc(CC(NC(C)=O)C(C)=O)cc1</smiles>

1: $\mathrm{R}=\mathrm{H} ; 2: \mathrm{R}=\mathrm{O} ; 3: \mathrm{R}=\mathrm{OH}$

Figure 1. The structures of compounds 1-5.

The known compounds were proved to be actinomycin D (1) [16-18], actinomycin V (2) [17,19], and actinomycin $X_{0 \beta}(3)[17,20]$ based on their nuclear magnetic resonance (NMR) and high resolution electrospray ionization mass spectroscopy (HRESIMS) (Figures S2-S70) data as well as a comparison of published data. The ${ }^{13} \mathrm{C}$ and ${ }^{1} \mathrm{H}$ NMR data of the three actinomycins are summarized in the Tables S2-S4 (Supplementary Materials).

Compound 4 has a molecular formula of $\mathrm{C}_{11} \mathrm{H}_{13} \mathrm{NO}_{4}$ deduced from its HRESIMS at $m / z[\mathrm{M}-\mathrm{H}]^{-}$ 222.0779 (calcd for $\mathrm{C}_{11} \mathrm{H}_{12} \mathrm{NO}_{4}, 222.0766$ ) and ${ }^{13} \mathrm{C}$ NMR data. The ${ }^{13} \mathrm{C}$ NMR spectrum of 1 exhibited 11 carbons including two carbonyls $(\delta 170.2,166.6)$, six aromatic carbons $(\delta 149.9,131.1,127.4,124.9$, $124.3,120.7)$, one methoxy $(\delta 51.8)$, and two methyls $(\delta 23.1,16.6)$. In the ${ }^{1} \mathrm{H}$ NMR spectrum, two aromatic proton signals appeared as doublets at $\delta 7.19(7.9 \mathrm{~Hz})$ and $7.07(7.9 \mathrm{~Hz})$ and were attributed to $\mathrm{H}-6$ and $\mathrm{H}-5$, three were singlets at $\delta 3.71,2.21,2.07$ and easily assigned to one methoxy and two methyls. In addition, a singlet at $\delta 9.68$ indicated the presence of an $\mathrm{NH}$ unit. HMBC correlations 
(Table 1 and Figure 2$)$ of both H-6 ( $\delta 7.19)$ and H-11 ( $\delta 3.71)$ with C-7 $(\delta 166.6)$ indicated the methoxy at C-7 position. Similarly, HMBC correlations of H-8 ( $\delta$ 2.21) with C-3 ( $\delta 149.9)$, C-4 ( $\delta 131.1)$, and C-5 ( $\delta$ 127.4) determined the position of a methyl at C-4, while the other methyl related to the acetylamino unit was deduced from a HMBC correlation of H-10 ( $\delta 2.07)$ with C-9 ( $\delta$ 170.2). The downfield chemical shift at $\delta 149.9$ (C-3), in combination of the HRESIMS data, suggested a hydroxyl at C-3. Based on the above NMR and MS data analyses, the structure of 4 was elucidated as 2-acetylamino-3-hydroxyl-4-methyl-benzoic acid methyl ester, a new compound. The ${ }^{13} \mathrm{C}$ and ${ }^{1} \mathrm{H}$ NMR data of 4 are listed in the Table 1. NMR and MS spectra of 4 see Figures S71-S81.

Table $1 .{ }^{13} \mathrm{C}$ and ${ }^{1} \mathrm{H}$ NMR data of compounds 4 and 5.

\begin{tabular}{|c|c|c|c|c|c|c|}
\hline \multirow{2}{*}{ No. } & \multicolumn{3}{|c|}{4} & \multicolumn{3}{|c|}{5} \\
\hline & ${ }^{13} \mathrm{C}$, Type & ${ }^{1} \mathrm{H}(J=\mathrm{Hz})$ & HМBC $(\mathrm{H} \rightarrow \mathrm{C})$ & ${ }^{13} \mathrm{C}$, Type & ${ }^{1} \mathrm{H}(J=\mathrm{Hz})$ & HМBC $(\mathrm{H} \rightarrow \mathrm{C})$ \\
\hline 1 & $124.3, \mathrm{C}$ & - & - & $124.5, \mathrm{C}$ & - & - \\
\hline 2 & $124.9, \mathrm{C}$ & - & - & $129.9, \mathrm{CH}$ & $6.92, \mathrm{~d}(8.2)$ & $C-4,6,7$ \\
\hline 3 & $149.9, \mathrm{C}$ & - & - & $112.1, \mathrm{CH}$ & $6.43, \mathrm{~d}(8.2)$ & $C-1,4,5$ \\
\hline 4 & 131.1, C & - & - & $148.8, \mathrm{C}$ & - & - \\
\hline 5 & $127.4, \mathrm{CH}$ & $7.07, \mathrm{~d}(7.9)$ & $C-1,3$ & $112.1, \mathrm{CH}$ & $6.43, \mathrm{~d}(8.2)$ & C- $-1,3,4$ \\
\hline 6 & $120.7, \mathrm{CH}$ & $7.19, \mathrm{~d}(7.9)$ & $C-2,4,7$ & $129.9, \mathrm{CH}$ & $6.92, \mathrm{~d}(8.2)$ & $C-2,4,7$ \\
\hline 7 & 166.6, C & - & - & $35.0, \mathrm{CH}_{2}$ & $\begin{array}{l}2.56 \text {, dd }(14.0,9.0) \\
2.80 \text {, dd }(14.0,5.4)\end{array}$ & $C-1,2,6,8,9$ \\
\hline 8 & $16.6, \mathrm{CH}_{3}$ & $2.21, \mathrm{~s}$ & $C-3,4,5$ & 61.0, $\mathrm{CH}$ & $4.27, \mathrm{~m}$ & $C-1,7,9,12$ \\
\hline 9 & $170.2, \mathrm{C}$ & - & - & $208.5, C$ & - & - \\
\hline 10 & $23.1, \mathrm{CH}_{3}$ & $2.07, \mathrm{~s}$ & C-9 & $27.5, \mathrm{CH}_{3}$ & $2.02, \mathrm{~s}$ & $C-8,9$ \\
\hline 11 & $51.8, \mathrm{CH}_{3}$ & $3.71, \mathrm{~s}$ & C-7 & $30.2, \mathrm{CH}_{3}$ & $2.61, \mathrm{~s}$ & C-4 \\
\hline 12 & & & & $170.4, \mathrm{C}$ & - & - \\
\hline 13 & & & & $22.5, \mathrm{CH}_{3}$ & $1.80, \mathrm{~s}$ & C-12 \\
\hline $\mathrm{NH}$ & & $9.68, \mathrm{~s}$ & & & $8.21, \mathrm{~d}(6.8)$ & $C-7,8,12$ \\
\hline
\end{tabular}

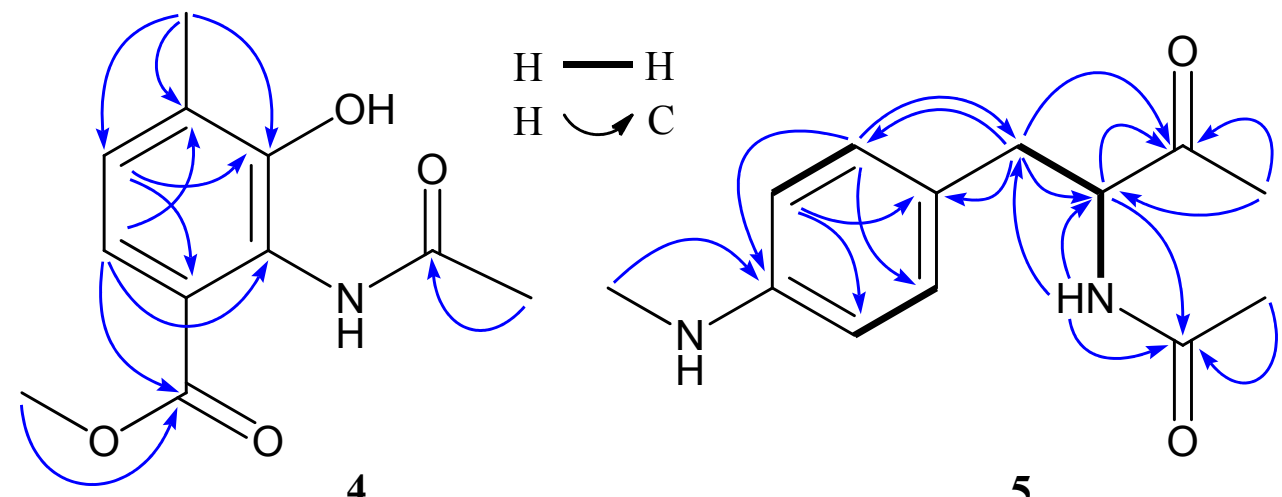

Figure 2. ${ }^{1} \mathrm{H}-{ }^{1} \mathrm{H}$ COSY and key HMBC correlations of compounds 4 and 5.

Compound 5 was isolated as a yellow oily and has UV absorbance at 252 and $303 \mathrm{~nm}$. Its HRESIMS showed $[\mathrm{M}+\mathrm{H}]^{+}$ion at $m / z 235.1443$ and $[\mathrm{M}+\mathrm{Na}]^{+}$ion at 257.1263, supporting a molecular formula of $\mathrm{C}_{13} \mathrm{H}_{18} \mathrm{~N}_{2} \mathrm{O}_{2}$. The ${ }^{13} \mathrm{C}$ and ${ }^{1} \mathrm{H}$ NMR spectra of 5 showed one ketone $\left(\delta_{\mathrm{C}} 208.5\right)$, one carbonyl $\left(\delta_{\mathrm{C}} 170.4\right)$, six aromatic carbons with four protons $\left(\delta_{\mathrm{C}} 148.8,129.9,129.9,124.5,112.1,112.1 ; \delta_{\mathrm{H}} 6.92,2 \mathrm{H}, \mathrm{d}, 6.43\right.$, $2 \mathrm{H}, \mathrm{d})$, one nitrogenated methine $\left(\delta_{\mathrm{C}} 61.0 ; \delta_{\mathrm{H}} 4.27\right)$, one methylene $\left(\delta_{\mathrm{C}} 35.0 ; \delta_{\mathrm{H}} 2.56,2.80\right)$, and three methyls $\left(\delta_{C} 30.2,27.5,22.5 ; \delta_{\mathrm{H}} 2.61,2.02,1.80\right)$. The ${ }^{1} \mathrm{H}$ NMR spectrum also exhibited a doublet at $\delta 8.21(1 \mathrm{H}, \mathrm{d}, 6.8 \mathrm{~Hz})$, which was attributed to the $\mathrm{NH}$ unit at $\mathrm{C}-8$ position. Two doublets at $\delta_{\mathrm{H}} 6.92$ $(2 \mathrm{H}, \mathrm{d}, 8.2 \mathrm{~Hz})$ and $\delta_{\mathrm{H}} 6.43(2 \mathrm{H}, \mathrm{d}, 8.2 \mathrm{~Hz})$ correlating with the carbon signals at $\delta_{\mathrm{C}} 129.9(\mathrm{CH})$ and $\delta_{\mathrm{C}}$ $112.1(\mathrm{CH})$ observed in the HSQC spectrum, together with the COSY correlation of H-5 $(\delta 6.43)$ and $\mathrm{H}-6(86.92)$, indicated that the benzene ring had a symmetrical structure. ${ }^{1} \mathrm{H}-{ }^{1} \mathrm{H}$ COSY correlations (Figure 2) of H-7 $(\delta 2.56,2.80)$ with H-8 $(\delta 4.27)$ and H-8 with NH-8 $(\delta 8.21)$ confirmed the connection 
of $\mathrm{CH}_{2}(7)-\mathrm{CH}(8)-\mathrm{NH}(8)$. The HMBC correlations (Table 1 and Figure 2) of H-7, H-8, H-10 with C-9 $(\delta 208.5)$ and $\mathrm{H}-11(\delta 2.61)$ with $\mathrm{C}-4(\delta 148.8)$ determined the ketone at $\mathrm{C}-9$ position and the $-\mathrm{NHCH}_{3}$ unit at $\mathrm{C}-4$, while the acetylamino group at $\mathrm{C}-8$ position was indicated by HMBC correlations of $\mathrm{H}-8$ and H-13 ( $\delta 1.80)$ with C-12 ( $\delta 170.4)$ and NH-8 with C-7 ( $\delta 35.0), \mathrm{C}-8(\delta 61.0)$, and C-12. The planar structure of 5 was thus determined as N-1-(4-methylaminophenylmethyl)-2-oxo-propyl acetamide. Compound 5 is closely related to $N$-acetyl-phenylalanine. The (S)- $N$-acetyl-phenylalanine and (R)- $N$-acetyl-phenylalanine could be assigned based on their optical rotation values, whereby a positive value indicated a $S$-configuration, while a negative value was suggestive of a $R$-configuration $[21,22]$. Accordingly, the stereochemistry of C-8 in compound 5 was deduced to be $S$-configuration because 5 had a positive optical rotation. Based on the above evidences, compound $\mathbf{5}$ was identified as $\mathrm{N}$-1S-(4-methylaminophenylmethyl)-2-oxo-propyl acetamide, a new compound. The ${ }^{13} \mathrm{C}$ and ${ }^{1} \mathrm{H}$ data of 5 were unambiguously assigned by using HSQC and HMBC correlations (Table 1 and Figure 2). NMR and MS spectra of 5 see Figures S82-S95. To the best of our knowledge, this class of new compound 5 is found from a natural resource for the first time.

All the isolated compounds (1-5) from this study were evaluated for their activity against the growth of methicillin-resistant S. aureus, E. coli, and C. albicans using the micro broth dilution method. Gentamicin (an antibiotic against both Gram-positive and negative bacteria) and amphotericin B (an antifungal drug) were used as positive control. The results (Table 2) showed that all three actinomycins significantly inhibited the growth of both bacteria and fungi with MIC values of 0.08 to $9.96 \mu \mathrm{M}$ for actinomycin D (1), 0.08 to $9.85 \mu \mathrm{M}$ for actinomycin $\mathrm{V}(\mathbf{2})$, and 0.61 to $9.83 \mu \mathrm{M}$ for actinomycin $\mathrm{X}_{0 \beta}$ (3). The control gentamicin showed activity with MIC 0.26 to $0.51 \mu \mathrm{M}$ against both S. aureus and E. coli, and amphotericin B was active with MIC $0.05 \mu \mathrm{M}$ for C. albicans. However, new compounds 4 and 5 at concentration of $100 \mu \mathrm{M}$ had no activity against the three tested pathogens.

Table 2. Antimicrobial activity of actinomycins D (1), V (2), and $X_{0 \beta}$ (3) (MIC: $\left.\mu \mathrm{M}\right)$.

\begin{tabular}{cccccc}
\hline Microbes & Actinomycin D (1) & Actinomycin V (2) & Actinomycin $\mathbf{X}_{\mathbf{0} \boldsymbol{\beta}}$ (3) & Gentamicin & Amphotericin \\
\hline S. aureus & 0.08 & 0.08 & 0.61 & 0.26 & - \\
E. coli & 0.12 & 0.12 & 0.61 & 0.51 & - \\
C. albicans & 9.96 & 9.85 & 9.83 & - & 0.05 \\
\hline
\end{tabular}

Compounds 1-5 were also tested for their activity in inhibiting the proliferation of human glioma U251 and SHG44 cells and rat glioma C $_{6}$ cells by an SRB assay, a method that measures total cellular protein content. Doxorubicin (DOX) [23] was used as a positive control. Glioma cells were treated with tested compounds for $72 \mathrm{~h}$ at different concentrations. The data (Table 3) obtained from this study indicated that three actinomycins had potent activity against the proliferation of the three tested tumor cell lines with $\mathrm{IC}_{50}$ values from 1.01 to $10.06 \mathrm{nM}$ for actinomycin $\mathrm{D}(\mathbf{1}), 0.42$ to $1.80 \mathrm{nM}$ for actinomycin $\mathrm{V}(2), 3.26$ to $25.18 \mathrm{nM}$ for actinomycin $\mathrm{X}_{0 \beta}$ (3), while the control DOX showed activity with $\mathrm{IC}_{50}$ values in a range from 0.70 to $9.61 \mu \mathrm{M}$. Unfortunately, new compounds 4 and 5 were inactive.

Table 3. Antiproliferative activity of actinomycins D (1), V (2), and $\mathrm{X}_{0 \beta}$ (3) against glioma cells ( $\left.\mathrm{IC}_{50}\right)$.

\begin{tabular}{|c|c|c|c|c|}
\hline Glioma Cells & $\begin{array}{c}\text { Actinomycin D } \\
(1, n M)\end{array}$ & $\begin{array}{c}\text { Actinomycin } A_{5} \\
(2, n M)\end{array}$ & $\begin{array}{c}\text { Actinomycin } X_{0 \beta} \\
(3, n M)\end{array}$ & $\operatorname{DOX}(\mu \mathrm{M})$ \\
\hline U251 & $10.06 \pm 0.68$ & $1.80 \pm 0.19$ & $8.71 \pm 0.66$ & $9.61 \pm 1.25$ \\
\hline SHG44 & $3.31 \pm 0.25$ & $1.37 \pm 0.07$ & $3.26 \pm 0.32$ & $2.54 \pm 0.23$ \\
\hline $\mathrm{C}_{6}$ & $1.01 \pm 0.05$ & $0.42 \pm 0.23$ & $25.18 \pm 0.47$ & $0.70 \pm 0.01$ \\
\hline
\end{tabular}

Actinomycin D (1) was further investigated for its effects on several important tumor metabolic enzymes from different metabolic pathways including HK2 [24,25] and PKM2 [25,26] from glycolysis, GLS $[27,28]$ from glutaminolysis, and FASN $[28,29]$ from lipogenesis. These metabolic regulators have 
been demonstrated to be upregulated in the glioma cells and are preferentially used by cancer cells, making them promising targets for the discovery of novel anticancer drugs [24-29]. U87-MG cells were treated by actinomycin D $(1,0.01 \mathrm{nM})$ for $48 \mathrm{~h}$. Protein prepared from the actinomycin D-treated U87-MG cells was subjected to a Western blot analysis. The results showed that actinomycin D (1) significantly reduced the expression levels of HK2, GLS, and FASN (Figure 3), suggesting that targeting multiple metabolic enzymes may be one of actinomycin D's anti-glioma mechanisms.

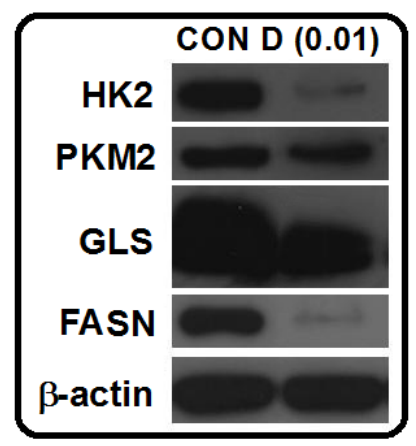

Figure 3. Effects of actinomycin D (1) on the expression levels of HK2, PKM2, GLS, and FASN in U87-MG cells. U87-MG cells were treated with actinomycin D (1, $0.01 \mathrm{nM})$ for $48 \mathrm{~h}$. Protein extracted from cells was subjected to a Western blot analysis (HK2: hexokinase 2; PKM2: pyruvate kinase M2; GLS: glutaminase; FASN: fatty acid synthase; $\beta$-actin: internal control).

Actinomycins are a family of chromopeptide lactone antibiotics, among which actinomycin D is one of the older anticancer drugs and has been studied extensively and widely used clinically for the treatment of several types of malignant tumors, such as Wilms' tumor and childhood rhabdomyosarcoma [20]. Despite their initial discovery more than 70 years ago, actinomycins continue to be a focus of many research areas, especially in their biological activity and medicinal use. For example, actinomycin D has been reported to have potent activities against HIV and tuberculosis $[20,30,31]$. It is known that the antitumor mechanism of actinomycin D is to inhibit transcription by binding DNA at the transcription initiation complex and preventing elongation of the RNA chain by RNA polymerase [32]. In this study, actinomycin D was found to significantly downregulate the expression levels of several glioma metabolic enzymes, suggesting that targeting multiple metabolic regulators might be a new anti-glioma mechanism of actinomycin D.

\section{Materials and Methods}

\subsection{General Experimental Procedures}

NMR spectra were recorded on a Bruker 500 spectrometer (Fällanden, Switzerland) using standard pulse programs and acquisition parameters and chemical shifts were reported in $\delta(\mathrm{ppm})$ referencing to the NMR solvent used. Octadecyl-functionalized silica gel (Octadecylsilyl (ODS), Cosmosil $75 \mathrm{C}_{18}$-Prep, Nacalai Tesque Inc., Kyoto, Japan) was used for open column chromatography. HPLC separation was performed on an Agilent 1260 HPLC system with a Diode Array Detector (DAD) detector using a Zorbax SB-C ${ }_{18}$ column $(250 \times 9.4 \mathrm{~mm}, 5 \mu \mathrm{m}$, Agilent Technologies, Palo Alto, CA, USA). All solvents used for this study were purchased from the Sinopharm Chemical Reagent Co. Ltd. (Shanghai, China). Human glioma U251, HSG44, and U87-MG cells and rat glioma C6 cells were purchased from the Cell Bank of the Chinese Academy of Sciences. Methicillin-resistant S. aureus ATCC 43300, E. coli ATCC 25922, and C. albicans were gifts from Zhongjun Ma, Pinmei Wang, and Bin Wu, respectively. Doxorubicin (DOX, $>98.0 \%$ ) was ordered from Sigma-Aldrich, gentamicin (99.6\%) and amphotericin B (>95.0\%) from Meilune Biotechnology Co. Ltd. (Dalian, China). Nutrient Broth (NB), Mueller-Hinton Broth (MHB), and Gause's agar were purchased from Hangzhou Microbial Reagent 
Co. Ltd. (Hangzhou, China). BMPM liquid medium (glucose $20 \mathrm{~g}$, glycerol $20 \mathrm{~g}$, soy flour $10 \mathrm{~g}$, cotton seed embryo meal $10 \mathrm{~g}$, $\left(\mathrm{NH}_{4}\right)_{2} \mathrm{SO}_{4} 1 \mathrm{~g}, \mathrm{CaCO}_{3} 10 \mathrm{~g}, 1.0 \mathrm{~L}$ water) was made in our laboratory.

\subsection{Isolation and Identification of Strain ZZ338}

The strain ZZ338 was isolated from sea squirts collected in January 2016 off the coastal rocks of DongJi Island, close to the East China Sea. The sea squirts were grinded with sterile water in a mortar and then diluted to $1 \times 10^{-3} \mathrm{~g} / \mathrm{mL}$. The diluted liquid was coated on the surface of Gause's agar medium. After incubation at $28^{\circ} \mathrm{C}$ for 7 days, the ZZ338 colonies were grown and then transferred to a Gause's agar plate by using a sterile needle. After being cultured at $28{ }^{\circ} \mathrm{C}$ for 3 days, the single colony (ZZ338) grew well was transferred onto Gause's agar slants and stored at $4{ }^{\circ} \mathrm{C}$ for later use.

The taxonomic identity of strain ZZ338 was determined by 16S rDNA analysis, which was conducted by Majorbio (Shanghai, China). The top sequence using BLAST (nucleotide sequence comparison) was compared to the GenBank database. A voucher strain of Streptomyces sp. ZZ338 was preserved at the Laboratory of Institute of Marine Biology, Ocean College, Zhejiang University, China.

\subsection{Fermentation of Strain ZZ338}

Two different liquid media of Gause and BMPM were applied to culture the strain ZZ338. First, the single colony (ZZ338) was transferred into $250 \mathrm{~mL}$ of Gause's liquid media in a $500 \mathrm{~mL}$ Erlenmeyer flask and then incubated at $28{ }^{\circ} \mathrm{C}$ for 4 days on a rotary shaker (180 rpm) to prepare the seed broth. Secondly, the seed broth $(4 \mathrm{~mL})$ was inoculated into $250 \mathrm{~mL}$ of Gause's liquid media and BMPM's liquid media in $500 \mathrm{~mL}$ Erlenmeyer flasks and then incubated at $28^{\circ} \mathrm{C}$ for 8 days on a rotary shaker (180 rpm). A total of 20.0 L of Gause's fermentation broth and $0.25 \mathrm{~L}$ of BMPM's culture were made for this study.

\subsection{Isolation of Compounds $\mathbf{1 - 5}$}

The Gause's fermentation broth of strain ZZ338 (20.0 L) was filtered to harvest mycelia and filtrate. The mycelia were extracted with $\mathrm{MeOH}$ three times to give a $\mathrm{MeOH}$ extract and the filtrate was extracted with ethyl acetate three times to afford an EtOAc extract. The two extracts were combined and then fractionated on a column of ODS (600 g) eluting with $40 \%, 70 \%$, and $100 \% \mathrm{MeOH}$ to give three fractions of $40 \mathrm{M}, 70 \mathrm{M}$, and 100M. Fraction $100 \mathrm{M}$ was separated by HPLC using a Zorbax SB-C ${ }_{18}$ column $(250 \times 9.4 \mathrm{~mm}, 5 \mu \mathrm{m}$; mobile phase $90 \% \mathrm{MeOH}$; flow rate $1.0 \mathrm{~mL} / \mathrm{min}$; detection wavelength: $440 \mathrm{~nm}$ ) to give compounds $1\left(22.1 \mathrm{mg}, \mathrm{t}_{\mathrm{R}} 19.0 \mathrm{~min}\right), 2\left(96.10 \mathrm{mg}, \mathrm{t}_{\mathrm{R}} 16.9 \mathrm{~min}\right)$, and 3 $\left(5.40 \mathrm{mg}, t_{\mathrm{R}} 15.5 \mathrm{~min}\right)$. Compound $4\left(3.60 \mathrm{mg}, \mathrm{t}_{\mathrm{R}} 20.0 \mathrm{~min}\right)$ was obtained from fraction $70 \mathrm{M}$ by HPLC purification (mobile phase: 70\% MeOH; detection wavelength: $250 \mathrm{~nm}$ ).

The BMPM's fermentation broth $(0.25 \mathrm{~L})$ was extracted with $\mathrm{MeOH}$ three times. The concentrated $\mathrm{MeOH}$ extract was separated by an ODS column eluting with $30 \%, 50 \%, 70 \%$ and $100 \% \mathrm{MeOH}$ to give Frs. $30 \mathrm{M}, 50 \mathrm{M}, 70 \mathrm{M}$, and $100 \mathrm{M}$. Compound $5\left(26.20 \mathrm{mg}, \mathrm{t}_{\mathrm{R}} 19.0 \mathrm{~min}\right)$ was obtained from fraction $70 \mathrm{M}$ by HPLC purification (mobile phase: $50 \% \mathrm{MeOH}$; flow rate: $1.0 \mathrm{~mL} / \mathrm{min}$; detection wavelength: $252 \mathrm{~nm}$ ). Compound 2 was also found in the fraction $100 \mathrm{M}$ by HPLC analysis.

Actinomycin D (1): Red amorphous powder; molecular formula $\mathrm{C}_{62} \mathrm{H}_{86} \mathrm{~N}_{12} \mathrm{O}_{16} ; \mathrm{mp} 242-245{ }^{\circ} \mathrm{C}$ (lit. 244-246 $\left.{ }^{\circ} \mathrm{C}\right)$ [18]; UV $\lambda_{\max } 240,445 \mathrm{~nm} ;{ }^{13} \mathrm{C}$ NMR data $\left(125 \mathrm{MHz}\right.$, in $\left.\mathrm{CDCl}_{3}\right)$, see Table S2, ${ }^{1} \mathrm{H}$ NMR data $\left(500 \mathrm{MHz}\right.$, in $\mathrm{CDCl}_{3}$ ) see Table S3; HRESIMS $m / z[\mathrm{M}+\mathrm{H}]^{+} 1255.6426$ (calcd for $\left.\mathrm{C}_{62} \mathrm{H}_{87} \mathrm{~N}_{12} \mathrm{O}_{16}, 1255.6363\right)$.

Actinomycin V (2): Red amorphous powder; molecular formula $\mathrm{C}_{62} \mathrm{H}_{84} \mathrm{~N}_{12} \mathrm{O}_{17}$; UV $\lambda_{\max } 242$, $445 \mathrm{~nm} ;{ }^{13} \mathrm{C}$ NMR data $\left(125 \mathrm{MHz}\right.$, in $\left.\mathrm{CDCl}_{3}\right)$, see Table S2, ${ }^{1} \mathrm{H}$ NMR data $\left(500 \mathrm{MHz}\right.$, in $\left.\mathrm{CDCl}_{3}\right)$ see Table S3; HRESIMS $m / z$ [M + H] ${ }^{+} 1269.6131$ (calcd for $\mathrm{C}_{62} \mathrm{H}_{85} \mathrm{~N}_{12} \mathrm{O}_{17}, 1269.6156$ ), $[\mathrm{M}+\mathrm{Na}]^{+} 1291.5945$ (calcd for $\mathrm{C}_{62} \mathrm{H}_{84} \mathrm{~N}_{12} \mathrm{NaO}_{17}, 1291.5975$ ), $[\mathrm{M}-\mathrm{H}]^{-} 1267.5967$ (calcd for $\mathrm{C}_{62} \mathrm{H}_{83} \mathrm{~N}_{12} \mathrm{O}_{17}, 1267.5999$ ).

Actinomycin $\mathrm{X}_{0 \beta}$ (3): Red amorphous powder; molecular formula $\mathrm{C}_{62} \mathrm{H}_{86} \mathrm{~N}_{12} \mathrm{O}_{17} ; \mathrm{UV} \lambda_{\max } 239$, $445 \mathrm{~nm} ;{ }^{1} \mathrm{H}$ NMR data $\left(500 \mathrm{MHz}\right.$, in $\mathrm{CDCl}_{3}$ ) see Table S4; HRESIMS $m / z[\mathrm{M}+\mathrm{H}]^{+} 1271.6309$ (calcd for $\mathrm{C}_{62} \mathrm{H}_{87} \mathrm{~N}_{12} \mathrm{O}_{17}, 1271.6312$ ), [M - H] $]^{-} 1269.6110$ (calcd for $\mathrm{C}_{62} \mathrm{H}_{85} \mathrm{~N}_{12} \mathrm{O}_{17}, 1269.6156$ ). 
Compound 4: faint yellow amorphous powder; molecular formula $\mathrm{C}_{11} \mathrm{H}_{13} \mathrm{NO}_{4} ; \mathrm{UV}(\mathrm{MeOH}) \lambda_{\max }$ $(\log \varepsilon) 252$ (3.21), $304(2.95) \mathrm{nm} ;{ }^{13} \mathrm{C}$ NMR data $\left(125 \mathrm{MHz}\right.$, in DMSO- $\left.d_{6}\right)$ and ${ }^{1} \mathrm{H}$ NMR data $(500 \mathrm{MHz}$, in DMSO- $d_{6}$ ) see Table 1; HRESIMS $m / z$ [M - H] $]^{-} 222.0779$ (calcd for $\mathrm{C}_{11} \mathrm{H}_{12} \mathrm{NO}_{4}, 222.0766$ ).

Compound 5: yellow oily; molecular formula $\mathrm{C}_{13} \mathrm{H}_{18} \mathrm{~N}_{2} \mathrm{O}_{2} ; \mathrm{UV}(\mathrm{MeOH}) \lambda_{\max }(\log$ E) 208 (4.41), $252(4.13), 303(3.32) \mathrm{nm} ;[\alpha]_{\mathrm{D}}^{25}+25.6(c 0.10, \mathrm{MeOH}) ;{ }^{13} \mathrm{C}$ NMR data $\left(125 \mathrm{MHz}\right.$, in DMSO- $\left.d_{6}\right)$ and ${ }^{1} \mathrm{H}$ NMR data (500 MHz, in DMSO- $d_{6}$ ) see Table 1 ; HRESIMS $m / z[\mathrm{M}+\mathrm{H}]^{+} 235.1443$ (calcd for $\mathrm{C}_{13} \mathrm{H}_{19} \mathrm{~N}_{2} \mathrm{O}_{2}, 235.1447$ ), [ $\left.\mathrm{M}+\mathrm{Na}\right]^{+} 257.1263$ (calcd for $\mathrm{C}_{13} \mathrm{H}_{18} \mathrm{~N}_{2} \mathrm{NaO}_{2}, 257.1266$ ), [2M + Na] ${ }^{+} 491.2626$ (calcd for $\mathrm{C}_{13} \mathrm{H}_{18} \mathrm{~N}_{2} \mathrm{NaO}_{2}, 491.2634$ ).

\subsection{Antimicrobial Assay}

The micro broth dilution method, as described in the previous study [14], was used to determine the antimicrobial activity of the isolated compounds against the growth of methicillin-resistant Staphylococcus aureus ATCC 43300, Escherichia coli ATCC 25922, and Candida albicans. Gentamicin (an antibiotic against both Gram-positive and Gram-negative bacteria) and amphotericin B (an antifungal drug) were used as positive control.

\subsection{Tumor Cell Culture}

Human glioma U251 and rat glioma C6 cells were cultured in DMEM (Dulbecco's Modified Eagle Medium, Gibco, Grand Island, NY, USA) with 10\% FBS (Fetal Bovine Serum, PAA Laboratories Inc., Toronto, ON, Canada), human glioma SHG44 in RPMI-1640 (Roswell Park Memorial Institution 1640, Gibco, Grand Island, NY, USA), and human glioma U87-MG cells in MEM (Minimum Essential Medium, Gibco, Grand Island, NY, USA). All cells were incubated at $37^{\circ} \mathrm{C}$ in a humidified incubator with $5 \% \mathrm{CO}_{2}$. Cells were used for experiment after the third generation.

\subsection{Sulforhodamine B (SRB) Assay}

The previously described SRB assay $[10,11,15]$ was applied to evaluate the activity of isolated compounds to inhibit the proliferation of different glioma cell lines. Doxorubicin was used as a positive control. Briefly, glioma cells were treated with different concentrations of tested compounds after cells adhesion for $24 \mathrm{~h}$. After $72 \mathrm{~h}$ of the treatment, compound-treated cells were fixed with $50 \mu \mathrm{L}$ of $10 \%$ cold TCA solution at $4{ }^{\circ} \mathrm{C}$ for $1 \mathrm{~h}$, washed with distilled water five times, and then dried at room temperature. The dried cells were stained with $50 \mu \mathrm{L}$ of $0.4 \%$ SRB for ten minutes and rinsed with $1 \%$ acetic acid solution five times. After being dried, dye was dissolved in $10 \mathrm{mM}$ Tris buffer and measured at $515 \mathrm{~nm}$ on a microplate reader (Bio-Tech, Winooski, VT, USA).

\subsection{Western Blot Analysis}

A Western blot was used to determine the expression levels of tumor metabolic regulators. The detailed procedures, including protein sample preparation, determination of protein concentration, and a Western blot analysis was referred to a previous publication [12].

\section{Conclusions}

The bioactive metabolite-produced Streptomyces sp. strain, ZZ338, was isolated from sea squirts. This isolated actinomycete, cultured in two different media, produced known actinomycins D (1), $\mathrm{V}(2), \mathrm{X}_{0 \beta}$ (3) and new compounds of 2-acetylamino-3-hydroxyl-4-methyl-benzoic acid methyl ester (4) and N-1S-(4-methylaminophenylmethyl)-2-oxo-propyl acetamide (5). The three actinomycins significantly inhibited the growth of both bacteria and fungi and the proliferation of different glioma cell lines; and are the components responsible for the activity of the crude extract of strain ZZ338. Interestingly, actinomycins D (1) was found to downregulate several glioma metabolic enzymes of different metabolic pathways (glycolysis, glutaminolysis, and lipogenesis), suggesting that targeting multiple glioma metabolic regulators might be a new antitumor mechanism of actinomycin $\mathrm{D}$. To the 
best of our knowledge, such a possible mechanism for this class of actinomycins is the first report herein. Additionally, for the first time, the class of new compound 5 is found from natural resources.

Supplementary Materials: The following are available online at www.mdpi.com/1660-3397/14/10/181/s1, NMR and HRESIMS spectra (Figures S1-S95) of compounds 1-5 as well as other supporting data.

Acknowledgments: Authors greatly appreciate Jianyang Pan (Pharmaceutical Informatics Institute of Zhejiang University) for performing NMR spectrometry for structure elucidation. We also thank Bi-Run Lin (Institute of Plant Protection of Guangdong Academy of Agricultural Science) and Guang-Xiong Zhou (College of Pharmacy of Jinan University) for their help with sample collection. Zhongjun Ma, Pinmei Wang, and Bin Wu (Ocean College of Zhejiang University) were also much appreciated for donating samples of Staphylococcus aureus, Escherichia coli, and Candida albicans.

Author Contributions: X.Z. performed the isolation and culture of strain ZZ338 and the isolation and structural elucidation of compounds; W.C. and X.Y. conducted the bioactive assay; X.Y.L. and Z.Z. designed the experiments and wrote the paper.

Conflicts of Interest: The authors declare no conflict of interest.

\section{References}

1. Kamran, N.; Calinescu, A.; Candolfi, M.; Chandran, M.; Mineharu, Y.; Asad, A.S.; Koschmann, C.; Nunez, F.J.; Lowenstein, P.R.; Castro, M.G. Recent advances and future of immunotherapy for glioblastoma. Expert Opin. Biol. Ther. 2016, 16, 1245-1264. [CrossRef] [PubMed]

2. Chamberlain, M.C. Temozolomide: Therapeutic limitations in the treatment of adult high-grade gliomas. Expert Rev. Neurother. 2010, 10, 1537-1544. [CrossRef] [PubMed]

3. Piel, J. Metabolites from symbiotic bacteria. Nat. Prod. Rep. 2004, 21, 519-538. [CrossRef] [PubMed]

4. Taylor, M.W.; Radax, R.; Steger, D.; Wagner, M. Sponge-associated microorganisms: Evolution, ecology, and biotechnological potential. Microbiol. Mol. Biol. Rev. 2007, 71, 295-347. [CrossRef] [PubMed]

5. Searle, P.A.; Molinski, T.F. Phorboxazoles A and B: Potent cytostatic macrolides from marine sponge Phorbas species. J. Am. Chem. Soc. 1995, 117, 8126-8131. [CrossRef]

6. Dunlap, W.C.; Battershill, C.N.; Liptrot, C.H.; Cobb, R.E.; Bourne, D.G.; Jaspars, M.; Long, P.F.; Newman, D.J. Biomedicinals from the phytosymbionts of marine invertebrates: A molecular approach. Methods 2007, 42, 358-376. [CrossRef] [PubMed]

7. Molinski, T.F.; Dalisay, D.S.; Lievens, S.L.; Saludes, J.P. Drug development from marine natural products. Nat. Rev. Drug Discov. 2009, 8, 69-85. [CrossRef] [PubMed]

8. Gulder, T.A.; Moore, B.S. Chasing the treasures of the sea bacterial marine natural products. Curr. Opin. Microbiol. 2009, 12, 252-260. [CrossRef] [PubMed]

9. Rateb, M.E.; Ebel, R. Secondary metabolites of fungi from marine habitats. Nat. Prod. Rep. 2011, 28, $290-344$. [CrossRef] [PubMed]

10. Xin, W.; Ye, X.; Yu, S.; Lian, X.Y.; Zhang, Z. New capoamycin-type antibiotics and polyene acids from marine Streptomyces fradiae PTZ0025. Mar. Drugs 2012, 10, 2388-2402. [CrossRef] [PubMed]

11. Yu, S.; Ye, X.; Chen, L.; Lian, X.Y.; Zhang, Z. Polyoxygenated 24,28-epoxyergosterols inhibiting the proliferation of glioma cells from sea anemone Anthopleura midori. Steroids 2014, 88, 19-25. [CrossRef] [PubMed]

12. Yu, S.; Ye, X.; Huang, H.; Peng, R.; Su, Z.; Lian, X.Y.; Zhang, Z. Bioactive sulfated saponins from sea cucumber Holothuria moebii. Planta Med. 2015, 81, 152-159. [CrossRef] [PubMed]

13. Chen, L.; Liang, Y.; Song, T.; Anjum, K.; Wang, W.; Yu, S.; Huang, H.; Lian, X.Y.; Zhang, Z. Synthesis and bioactivity of tripolinolate A from Tripolium vulgare and its analogs. Bioorg. Med. Chem. Lett. 2015, 25, 2629-2633. [CrossRef] [PubMed]

14. Ye, X.; Anjum, K.; Song, T.; Wang, W.; Yu, S.; Huang, H.; Lian, X.Y.; Zhang, Z. A new curvularin glycoside and its cytotoxic and antibacterial analogues from marine actinomycete Pseudonocardia sp. HS7. Nat. Prod. Res. 2016, 30, 1156-1161. [CrossRef] [PubMed]

15. Liang, Y.; Xie, X.; Chen, L.; Yan, S.; Ye, X.; Anjum, K.; Huang, H.; Lian, X.Y.; Zhang, Z. Bioactive polycyclic quinones from marine Streptomyces sp. 182SMLY. Mar. Drugs 2016, 14. [CrossRef] [PubMed]

16. Ulrich, H.; Eberhard, B.; Gunther, J. ${ }^{13} \mathrm{C}$ nuclear magnetic resonance study of actinomycin D. J. Am. Chem. Soc. 1974, 96, 8036-8040. 
17. Mauger, A.B.; Thomas, W.A. NMR studies of actinomycins varying at the proline sites. Org. Magn. Reson. 1981, 17, 186-190. [CrossRef]

18. Cao, X.; Yang, R.L.; Yuan, X.W.; Xi, T.; Yang, Z.Z. Separation, purification, and structural identification of antitumor active components from marine actinomycete ACMA006. J. Oceanogr. Taiwan Haixia 2010, 30, 400-404.

19. Zhang, Z.; Peng, G.; Yang, G.; Xiao, C.L.; Hao, X.Q. Isolation, purification, identification of structures and study of bioactivity of anti-TB active component 9005B. Chin. J. Antibiot. 2009, 34, 399-402.

20. Chen, C.; Song, F.; Wang, Q.; Abdel-Mageed, W.M.; Guo, H.; Fu, C.; Hou, W.; Dai, H.; Liu, X.; Yang, N.; et al. A marine-derived Streptomyces sp. MS449 produces high yield of actinomycin $\mathrm{X}_{2}$ and actinomycin D with potent anti-tuberculosis activity. Appl. Microbiol. Biotechnol. 2012, 95, 919-927. [CrossRef] [PubMed]

21. Pakulski, Z.; Demchuk, O.M.; Frelek, J.; Luboradzki, R.; Pietrusiewicz, K.M. New monodentate p,c-stereogenic bicyclic phosphanes: 1-phenyl-1,3a,4,5,6,6a-hexahydrocyclopenta[b] phosphole and 1-phenyloctahydrocyclopenta[b]phosphole. Eur. J. Org. Chem. 2004, 18, 3913-3918. [CrossRef]

22. Emese, P.; József, S.; Ferenc, F.; Elemér, F. The influence of molecular structure and crystallization time on the efficiency of diastereoisomeric salt forming resolutions. Tetrahedron. Asymmetry 2010, 21, 2429-2434.

23. Tacara, O.; Sriamornsak, P.; Dass, C.R. Doxorubicin: An update on anticancer molecular action, toxicity and novel drug delivery systems. J. Pharm. Pharmacol. 2013, 65, 157-170. [CrossRef] [PubMed]

24. Wolf, A.; Agnihotri, S.; Micallef, J.; Mukherjee, J.; Sabha, N.; Cairns, R.; Hawkins, C.; Guha, A. Hexokinase 2 is a key mediator of aerobic glycolysis and promotes tumor growth in human glioblastoma multiforme. J. Exp. Med. 2011, 208, 313-326. [CrossRef] [PubMed]

25. Vander Heiden, M.G. Targeting cancer metabolism: A therapeutic window opens. Nat. Rev. Drug Discov. 2011, 10, 671-684. [CrossRef] [PubMed]

26. Kefas, B.; Comeau, L.; Erdle, N.; Montgomery, E.; Amos, S.; Purow, B. Pyruvate kinase M2 is a target of the tumor-suppressive microRNA-326 and regulates the survival of glioma cells. Neuro Oncol. 2010, 12, 1102-1112. [CrossRef] [PubMed]

27. Daye, D.; Wellen, K.E. Metabolic reprogramming in cancer: Unraveling the role of glutamine in tumorigenesis. Semin. Cell Dev. Biol. 2012, 23, 362-369. [CrossRef] [PubMed]

28. Ru, P.; Williams, T.M.; Chakravarti, A.; Guo, D. Tumor metabolism of malignant gliomas. Cancers 2013, 5, 1469-1484. [CrossRef] [PubMed]

29. Menendez, J.A.; Lupu, R. Fatty acid synthase and the lipogenic phenotype in cancer pathogenesis. Nat. Rev. Cancer 2007, 7, 763-777. [CrossRef] [PubMed]

30. Imamichi, T.; Murphy, M.A.; Adelsberger, J.W.; Yang, J.; Watkins, C.M.; Berg, S.C.; Baseler, M.W.; Lempicki, R.A.; Guo, J.; Levin, J.G.; et al. Actinomycin D induces high-level resistance to thymidine analogs in replication of human immunodeficiency virus type 1 by interfering with host cell thymidine kinase expression. J. Virol. 2003, 77, 1011-1020. [CrossRef] [PubMed]

31. Imamichi, T.; Conrads, T.P.; Zhou, M.; Liu, Y.; Adelsberger, J.W.; Veenstra, T.D.; Lane, H.C. A transcription inhibitor, actinomycin D, enhances HIV-1 replication through an interleukin-6-dependent pathway. J. Acquir. Immune Defic. Syndr. 2005, 40, 388-397. [CrossRef] [PubMed]

32. Sobell, H.M. Actinomycin and DNA transcription. Proc. Natl. Acad. Sci. USA 1985, 82, 5328-5331. [CrossRef] [PubMed]

(C) 2016 by the authors; licensee MDPI, Basel, Switzerland. This article is an open access article distributed under the terms and conditions of the Creative Commons Attribution (CC-BY) license (http://creativecommons.org/licenses/by/4.0/). 